\title{
NEW APPROACH IN TEACHING ENGLISH LANGUAGE IN THE GLOBALIZATION ERA
}

\author{
CGuzacheva N., ORCID: 0000-0003-1461-0718, Tashkent Pediatric Medical Institute, \\ Tashkent,Uzbekistan,gusacheva_nadia@mail.ru
}

\section{НОВЫЙ ПОДХОД В ОБУЧЕНИИ АНГЛИЙСКОМУ ЯЗЫКУ В ЭРУ ГЛОБАЛИЗАЦИИ}

\author{
СГузачева Н. И., ORCID: 0000-0003-1461-0718, Ташкентский педиатрический медицинский \\ институт, г. Ташкент, Узбекистан, gusacheva_nadia@mail.ru
}

Abstract. English language is identified as one of the most spread languages for the worldwide communication. The intensive globalization of the world in the last decades requires international communication within the wider range of nations and cultures. It is important to recognize the continuous shift of the role of the English language from a second language into the global nature of the English language, in the context of worldwide communication, stressing the fact, that English as a foreign language has become international language. Within the concept of English as a language used for international and intercultural communication, it is consequently important to consider the inseparable role of culture in a language as the cause of the shift from the cultural aspect in English as a second language into the intercultural aspects in English as an international language including consideration of its possible impact on teaching English as an international language.

Аннотация. Английский язык считается одним из самых распространенных языков для общения во всем мире. Интенсивная глобализация мира в последние десятилетия требует международного общения с более широким кругом стран и культур. Важно признать непрерывный рост роли английского языка как второго языка, подчеркивая тот факт, что английский как иностранный язык стал международным языком. Следовательно, в рамках концепции английского языка как языка, используемого для международного и межкультурного общения, важно рассматривать неразрывную роль культуры в языке как причину перехода от культурного аспекта английского языка как второго языка к межкультурным аспектам.

Keywords: foreign language, intercultural communication, global language.

Ключевые слова: иностранный язык, межкультурное общение, глобальный язык.

Globalization is the increasingly of relations of people, culture and economy. It can contribute to economic growth in different countries. The term can also refer to the transnational circulation of ideas, languages, and popular culture.

English, or better said, the concept of English language known as 'International English' is the global view of the language or an international standard for the language. It can also be referred as: Global English, World English or even Globish. Despite the arguing if it is a desired standardization or killing of the language, the focus here is to show that it is globally acknowledged to be the most global language of all times [1]. 
The phenomena globalization and the need for an efficient way of communication around the world is a fact which does not depend on our wanting or not, believing or not - it is a fact. The domain of English is, today a basic need for any professional in any major area. The internationalization of manpower made nations adopt English as the official language of the world, as said before and the learning of the language opens doors for personal, professional and cultural development [2].

English has become a language that people worldwide want to learn and speak fluently. The English language is global; and globalization is also reflected in the worldwide use of English language. As a result, English plays a vital role in many areas: education, science, technology, politics, and trade.

The concept of foreign language teaching in non-linguistic institutions aimed at the formation and development of professional foreign language communicative competence and foreign language is an integral component of the modern training specialist of any profile. Knowing foreign language is one of the indicators of educational level of the modern specialist.

Nowadays the globalization process is observed in the world- the appearance of hybrid world culture, the mixture of national traditions strengthening the cooperation between the nations. It is emerged in the unification and solidarity of the very different aspects of the people's life activities their perception of the world and outlook, policy and economics, social life and manufacture, science and education, culture and art, religion and the language, sports.

It is apparent that in the 21 st century, the trend of globalization is leading to closer relationships between countries. Of all the different languages, English is an international language. It is widely used in communication between people and countries. The English language has spread and developed globally, which is a fact that cannot be ignored.

The objective of University English is to develop students' ability to use English in an allround way, especially in listening and speaking, so that in their future work and social interactions they will be able to exchange information effectively through both spoken and written channels, and at the same time they will be able to enhance their ability to study independently and improve their cultural quality so as to meet the needs of Uzbekistan's social development and international exchanges.

Generally speaking, students who major in English are a minority at universities in Uzbekistan. More students will use English in future careers such as business, law, and journalism. English will be used as a tool to communicate or negotiate with different people after their graduation. In other words, the popularity of English worldwide provides a clear reason to reform English Language Teaching in Uzbekistan, get rid of exam-oriented education, and to focus on developing students' listening and speaking skills so they learn to communicate effectively with others.

University facilities and resources are also gradually improving comparing with the past decade. Multimedia teaching provides a platform for developing speaking skills by stimulating students' interest and participation in class [3].

While developing their speaking abilities and increasing their vocabulary level, students simultaneously develop their listening skill and also gain confidence during the process of communication. It is apparent that an English context is automatically created during various activities when implementing Communicative Language Teaching while English is used as the medium for students to communicate with each other. The English context can help students cultivate their sense of the language and create an atmosphere where students can improve their English ability. 
It is generally agreed that good teaching involves good communication between the teacher and students and also among students. The best productivity in a classroom comes from effective co-operation between the teacher and the students. Therefore, teachers' roles can be vital to the effectivity of the language learning. Teachers need to be supportive. A supportive teacher is one who creates efficiently a positive classroom environment, who encourages students to behave well in classroom and to be motivated. Supportive teachers also are teachers who emphasize the learning process by giving all the students the chance to construct their learning and be engaged with the content.

Communicative Language Teaching provides students an opportunity to speak and share ideas in a relatively relaxing way. Therefore, students become the protagonists in the classroom, and their initiative and motivation are both enhanced. A problem that the lack of an English context may block students' English study can be solved by implementing this teaching method, because Communicative Language Teaching not only focuses on developing students' listening and speaking skills of English, but also reading and writing skills.

Communicative instruction and cooperative learning provide students with the necessary skills to succeed while learning a foreign language because they allow students to be the center of the learning process and can positively affect students' learning, promoting good interaction. Therefore, it is time to change to a method that guarantees communication and interaction between teacher and students and promote a supportive relationship between them.

A traditional limitation to developing students' communicative competence is the inadequate interaction between teachers and students. Teachers simply spend much time lecturing while students take notes and seldom participate in class. The relatively tedious test-based teaching method makes students reluctant to freely participate in classroom discussions. Therefore, the communicative teaching approach is still on a journey from theory to practice in universities of Uzbekistan.

Although some universities pay more attention to developing students' communicative competence, the traditional assessing system is still ingrained, and the dichotomy between "accuracy" and "fluency" is still worth considering if this teaching method will be more widely implemented in Uzbekistan [4].

Communicative Language Teaching can introduce new teaching methods, creating a diversified teaching process. Teachers can use various resources to help students develop their communicative skills, which is another manifestation of the diversity of the teaching method. For example, English teachers can use pictures to promote group discussions, thereby helping students understand the informational and cultural background of various topics. Games can also be used to help students learn vocabulary and practice their writing skills. More specifically, teachers can help students create an English context when teaching grammar and Western culture. During group discussions, students not only practice their spoken English, but also learn about different cultures. Grammar can also be practiced during this process.

The use of Communicative Language Teaching will produce new English speakers, especially in Uzbekistan. We should also understand that it is necessary for University English to have reasonable objectives and requirements, and that it is necessary to improve current teaching methods to improve students' oral English proficiency. Developing students' communicative competence is mandatory for English Language Teaching in universities of Uzbekistan and should be a priority when teaching and learning English today.

Cooperative learning helps students to increase achievement and help students to improve their attitude toward school, learning and classmates. It also helps students to work cooperatively as a team and learn critical thinking while working and making part of a group. Additionally, 
cooperative learning supports communicative language teaching. The activities and strategies used in cooperative learning are helpful to promote cooperation, interaction among students, which will promote real communication and benefit students' own learning construction. Students will use language in a soft way, and also in different context which helps to improve students' communicative competence [5].

The benefits of having a supportive and caring teacher influences positively the relationship between teacher and students in the classroom and this is easily proven by the results of the surveys. Students believe that they perform better in classes where they feel that the environment is safe, the teacher is there to help and support them and in classes where they are at the center of the learning process.

Communication and interaction are the key to achieve success; moreover, they believe that the communicative language teaching offers them the opportunity to interact and build their own learning. Students, additionally, takes advantages of cooperative learning. It allows them to feel engaged in the learning process and learn from a perspective of teamwork which favors students who are most in need. Even though all the constraints a teacher can face while implementing the communicative language teaching, and cooperative learning, both are seen as great tools to increase students' interaction and communicative competence ability. The most challenging problem a teacher can face is related to the materials, in this case authentic materials, and student's English language proficiency.

Universities English teachers should be armed with sufficient knowledge to guide students in the process of learning English. Therefore, it is promising to implement integrated skills into English teaching when promoting the communicative teaching approach [6].

The importance of knowing the English language resides on knowing the knowledge and using it. Therefore while using the language it is essential that the user has a theoretical comprehension of what language is from the point of the knowledge needed to use it and from the point of the use that is made from these acknowledgement, to build meanings in the social world.

The use of the language - verbal and visual — is essentially determined by its social and interactive nature, for who uses it, considers the person to whom is directing to, or who made an announcement by. All meaning is dual, in other words, it is built by its participants of the speech. Besides that, every interactive meeting is crucially marked by a social world which evolves it, by an institution, by the culture and by history. It means that counteraction events do not occur in vain or in a social vacuum; quite the contrary, when envelops in an written interaction, or oral, people do it to act in the social world, in a determined moment and space, in relation to whom they direct to or by who they were direct to. In this sense the construction of the meaning is social [7].

With the spread and development of English around the world and its increased use in Uzbekistan, research about improved methods to develop university students' English level has become of great importance. This has promoted changes in both the teaching and learning process.

The demand to the specialists who is proficient in foreign languages is increasing in our independent republic now. In particular, English is also considered to be one of the demanding languages of our life. Of course, it is not a secret, that there is being given a high attention to the teaching English language. In order to create harmoniously developed, highly educated, modernthinking young generation the first President of the Republic of Uzbekistan Islam Karimov signed a Decree "On measures to further improvement the learning system of foreign languages" [8].

Discussing the intercultural communication, an English language could be identified as one of the most spread languages for the worldwide communication. Within the concept of English as a language used for international and intercultural communication, it is important to consider the inseparable role of culture in a language as the cause of the shift from the cultural aspect in English 
as a second language into the intercultural aspects in English as an international language. For the teachers of English as a foreign language it is important to realize that the last decade the role of English language is considered to be as a global language for communication, which resulted into its status of English as an international language.

Consequently, the status of global language implies the multicultural settings of the English as an international language and within the context of foreign or 'international' language acquisition, it is also essential to understand that a skilled language teacher should be the one who could help to eliminate the negative impact of the potential cultural misunderstandings within intercultural communication by the qualified, well-structured introduction of the intercultural studies to students. The language teacher should be their good guide to help them to reach consciously competent stage of cultural-awareness, including equipping the students with the basic knowledge about cultural specifications within pre-defined categories of intercultural differences to avoid or at least decrease the confusion and frustrations of students streaming from intercultural misunderstandings.

Learning foreign languages is connected with the accumulation of diverse information, and it develops a culture of mental work. The learning process promotes the development of important personality traits. Individual abilities will be improved during the lessons. On the lessons of foreign languages, the speech is formed, interpersonal relations are developed. During the speaking, writing and reading the speech automatisms, skills and abilities, audio and visual perception are being developed. Language also influences to cognitive functions, forming intellection logics, it promotes the development of cognitive functions of mind, educates various methods of memorizing.

The world knowledge refers to the conventional knowledge which people have over worldly things. The acknowledgement of the world is recorded in the memory of people on various things built in one's life.

\section{References:}

1. Block, D. (2015). Globalization and Language Teaching. Londres, Routledge.

2. Bygate, M. (2016). The Cambridge Guide to Teaching English to Speakers of Other Languages. Cambridge, Cambridge University Press.

3. Graddol, D. (2016). The future of English? A guide to forecasting the popularity of the English language in the 21st century. The English Company (UK) Ltd.

4. Postanovlenie Pervogo Prezidenta Respubliki Uzbekistan Karimova I. A. no. PP-1875 “O merakh po dal'neishemu sovershenstvovaniyu sistemy izucheniya inostrannykh yazykov", 10.12. 2012.

5. Khallieva, D. (2016). The significance of learning foreign languages in the era of Globalization. University Press.

6. Kramsch, C. (2014). Teaching foreign languages in an era of globalization: Introduction. The modern language journal, 98(1), 296-311. https://doi.org/10.1111/j.1540-4781.2014.12057.x

7. Alamelu, C., \& Menon, S. U. (2018). Metamorphosis of language teaching methods leading to post method era-an overview. International Journal of English Language, Literature in Humanities, 6(12), 15-15.

8. Lee, J. S., Nakamura, Y., \& Sadler, R. (2018). Effects of videoconference-embedded classrooms (VEC) on learners' perceptions toward English as an international language (EIL). ReCALL, 30(3), 319-336. https://doi.org/10.1017/S095834401700026XP

\section{Список литературы:}

1. Block D. Globalization and Language Teaching. Londres: Routledge. 2015. 
2. Bygate M. The Cambridge Guide to Teaching English to Speakers of Other Languages. Cambridge: Cambridge University Press, 2016.

3. Graddol D. The future of English? A guide to forecasting the popularity of the English language in the 21st century. The English Company (UK) Ltd, 2016.

4. Постановление Первого Президента Республики Узбекистан Каримова И. А. №ПП1875 «О мерах по дальнейшему совершенствованию системы изучения иностранных языков». 10.12. 2012.

5. Khallieva D. The significance of learning foreign languages in the era of Globalization. University Press, 2016.

6. Kramsch C. Teaching foreign languages in an era of globalization: Introduction // The modern language journal. 2014. V. 98. №1. P. 296-311. https://doi.org/10.1111/j.15404781.2014.12057.x.

7. Alamelu C., Menon S. U. Metamorphosis of language teaching methods leading to post method era-an overview // International Journal of English Language, Literature in Humanities. 2018. V. 6. №12. P. 15-15.

8. Lee J. S., Nakamura Y., Sadler R. Effects of videoconference-embedded classrooms (VEC) on learners' perceptions toward English as an international language (EIL) // ReCALL. 2018. V. 30. №3. P. 319-336. https://doi.org/10.1017/S095834401700026XP.

Работа поступила

в редакциюю 10.03.2019 2.
Принята к публикациии 15.03.2019 2.

Cite as (APA):

Guzacheva, N. (2019). New Approach in Teaching English Language in the Globalization Era. Bulletin of Science and Practice, 5(4), 498-503. https://doi.org/10.33619/2414-2948/41/75.

Ссылка для циитирования:

Guzacheva N. New Approach in Teaching English Language in the Globalization Era // Бюллетень науки и практики. 2019. Т. 5. №4. С. 498-503. https://doi.org/10.33619/2414$2948 / 41 / 75$. 